\title{
MEDIA KERTAS LIPAT SEBAGAI UPAYA MENINGKATKAN HASIL BELAJAR MATEMATIKA MATERI PECAHAN SEDERHANA PADA KELAS IV DI MI MURNI SUNAN DRAJAT LAMONGAN
}

\author{
${ }^{1}$ Nailun Najiyyah, ${ }^{2}$ Silviana Nur Faizah \\ ${ }^{1,2}$ Universitas Islam Lamongan \\ e-mail: ${ }^{1}$ nailunnajiyyah@gmail.com, ${ }^{2}$ silviana_nurfaizah@unisla.ac.id
}

\begin{abstract}
Teaching media is a knowledge of the teaching methods used by a teacher or instructor. The method is the method used to achieve the stated goals. Another technique is the presentation technique mastered by the teacher to teach or present learning material to students in the classroom, so that the lesson can be absorbed, understood and utilized by students properly. The better the teaching method, the more effective the achievement of objectives. In reality, the teaching method or method used conveys different information in ways that are used to strengthen students in mastering knowledge, skills and attitudes (cognitive, psychomotor, affective). Specifically the method of teaching in the classroom, the effectiveness of a method is influenced by the goals, student factors, situation factors, and the teacher's own factors. This study aims to determine the effectiveness of the demonstration and recitation methods in increasing student learning motivation in fiqh subjects in class 2 MI. This research is a classroom action research, research instrument using observation sheets and interviews. Data analysis uses a research cycle and is described qualitatively. The results showed an increase in student motivation in fiqh subjects using the method of demonstration and recitation.
\end{abstract}

Keywords: Methode, Demonstration, Resitasi, Motivation Learning

\section{A. Pendahuluan}

Matematika adalah suatu pengetahuan yang telah ditata secara teratur menggunakan suatu kerangka tertentu (Nasution, 1992). Konsep-konsep dan struktur abstrak yang terdapat dalam matematika, serta mencari hubungan antara konsep-konsep dan struktur matematika. Belajar matematika harus melalui proses yang bertahap dari konsep yang sederhana ke konsep yang lebih kompleks. Setiap konsep matematika dapat dipahami dengan baik jika pertama-tama disajikan dalam bentuk yang konkrit.

Matematika merupakan salah satu bidang studi yang menduduki peranan penting dalam pendidikan, hal ini dapat dilihat dari waktu jam pelajaran sekolah lebih banyak dibandingkan pelajaran lain. Pelajaran matematika dalam pelaksanaan pendidikan diberikan kepada semua jenjang pendidikan. Pembelajaran matematika bagi siswa sekolah dasar merupakan usaha pembentukkan pola pikir dalam pemahaman suatu pengertian atau dalam penalaran suatu hubungan di antara pengertian-pengertian tersebut.Pembelajaran matematika siswa dibiasakan untuk memperoleh pemahaman dari 
pengalaman sehari-hari. Siswa diberi pengalaman menggunakan matematika sebagai alat untuk memahami ataupun menyampaikan informasi, misalnya mengenai persamaan-persamaan dan tabel-tabel dalam matematika.

Materi matematika di sekolah dasar diantaranya pengukuran (waktu, berat, dan jarak), Faktor Persekutuan Terbesar (FPB), Kelipatan Persekutuan Terkecil (KPK), pecahan, keliling dan luas bangun datar, luas permukaan dan volume bangun ruang, serta pengolahan data (rata-rata, median, modus, dll). Matematika perlu diberikan kepada siswa sekolah dasar guna untuk membekali mereka dengan kemampuan berpikir logis, analitis, sistematis, kritis, dan kreatif serta memiliki kemampuan bekerjasama. Diharapkan dengan bekal tersebut siswa dapat menerapkannya dalam kehidupan seharihari (Titikusumawati, 2014).

Tujuan pembelajaran matematika di SD/MI dapat dilihat dalam kurikulum tingkat satuan pendidikan 2006 SD. Mata pelajaran matematika bertujuan agar peserta didik memiliki kemampuan sebagai berikut: 1) memahami konsep matematika, menjelaskan keterkaitan antar konsep dan mengaplikasikan konsep secara luwes, akurat, efisien, dan tepat dalam pemecahan masalah. 2) menggunakan penalaran pada pola dan sifat, melakukan manipulasi matematika dalam membuat generalisai, menyusun bukti, atau menjelaskan gagasan dan pernyataan matematika. 4) mengkomunikasikan gagasan dan simbol, tabel, diagram atau media lain untuk memperjelas masalah. 5) memiliki sikap menghargai kegunaan matematika dalam kehidupan, yaitu rasa ingin tahu, perhatian dan minat dalam mempelajari matematika sifat-sifat ulet dan percaya diri dalam pemecahan masalah (Admin, 2011).

Pecahan sederhana merupakan salah satu materi yang diajarkan pada siswa kelas IV.Bilangan pecahan adalah bilangan yang merupakan hasil bagi antara bilangan bulat dan bilangan asli, yang dimana bilangan yang dibagi nilainya lebih kecil dari bilangan penyebutnya atau bilangan pembaginya. Untuk lebih memudahkan kita dalam mengartikanya adalah bilangan yang terdiri dari 2 angka, yaitu angka pembilang dan angka pembagi (penyebut). Bilangan pecahan berbentuk $a / b$ dengan $b=/ 0$, disebutkan bahwa $\mathrm{a}=$ pembilang dan $\mathrm{b}=$ penyebut.

Namun kenyataannya, sebagian siswa masih mengalami kesulitan dalam memahami konsepnya. Hal tersebut disebabkan oleh beberapa faktor diantaranya kemampuan penguasaan konsep yang kurang maksimal, metode mengajar yang kurang bervariasi dan juga media yang tidak diterapkan. Seperti halnya kendala pembelajaran matematika di MI Ma'arif $\mathrm{Nu}$ Sunan Drajat Lamongan yaitu siswa mengalami kesulitan pada pokok bilangan pecahan yaitu kesulitan prinsip dalam mengoperasikan bilangan pecahan seperti penjumlahan, perkalian dan pembagian serta mengalami kesulitan verbal yang disebabkan karena kurang teliti dan merasa tidak perlu. Hal ini dapat dilihat ketika mengerjakan soal-soal matematika yang menyangkut dengan 
operasi pecahan, artinya sebagian besar dari siswa kelas IV MI Ma'arif Nu Sunan Drajat masih lemah dalam menguasai konsep menghitung bilangan pecahan, sebagai dasar untuk mencapai prestasi belajar matematika yang memadai.

Hasil nilai ulangan harian siswa kelas IV MI Ma'arif NU Sunan Drajat Lamongan. tahun pelajaran 2018/2019 menunjukkan bahwa perolehan nilai murni ratarata kelas adalah 58\% di bawah KKM. Perolehan nilai secara individu yang tergambar bahwa 11 dari 34 siswa memperleh nilai dibawah KKM. 11 dari 34 siswa menjawab salah pada soal-soal pemecahan masalah yang berkaitan dengan pecahan sederhana.

Jika dalam sebuah pembelajaran hanya menerapkan konsep dengan tulisan ataupun kata-kata maka pembelajaran tersebut tidak akan bermakna bagi siswa. Jadi setiap pembelajaran membutuhkan media agar pembelajaran itu bermakna dan mengena pada diri siswa. Hal itu sejalan dengan karakteristik anak sekolah dasar yaitu senang bermain, senang bergerak, senang bekerja dalam kelompok, dan senang merasakan atau melakukan sesuatu secara langsung (Syaodih, 2006).

SAtu diatara beberapa cara yang dapat digunakan guru untuk menciptakan suasana bermakana pada pembelajaran matematika materi pecahan adalah dengan menggunakan media kertas lipat. Kertas lipat adalah suatu media visual dalam pembelajaran matematika, yang merupakan inovasi baru sebagai media pembelajran matematika. Kertas lipat merupakan media pembelajaran aktif yang mangajak peserta didik untuk belajar aktif dalam memecahkan persoalan atau mengaplikasikan apa yang baru mereka pelajari ke dalam kehidupan nyata (zaini, dkk, 2008).

Adapun kelebihan dari media Kertas Lipat adalah dapat meningkatkan kreatifitas dalam membuat alat ini, siswa menjadi lebih aktif dalammemperoleh pembelajaran yang bermakna dari media Kertas Lipat, dapat melatih komunikasi siswa dalam kelompok, menimbulkan motivasi, dan menimbulkan keceriaan serta menarik perhatian siswa saat mempraktikkan kertas lipat yang berwarna.

Berdasarkan uraian diatas Media Kertas Lipat menjadi alternatif dalam mengatasi kendala yang dihapai siswa dalam menyelesaikan pembelajaran matematika pada materi Pecahan Sederhana di Mi Ma'arif Nu Sunan Drajat Lamongan kelas IV. Sehingga diharapkan selain mampu menjadi media pembelajaran matematika yang menyenangkan.

\section{Media Kertas Lipat}

Media pembelajaran merupakan alat bantu yang berfungsi untuk menjelaskan sebagian dari keseluruan program pembelajaran yang sulit dijelaskan secara verbal. Materi pembelajaran akan terasa lebih mudah dan jelas jika dalam pembelajaran menggunakan media, fungsi media dalam pembelajaran adalah sebagai penjelas pesan (Musfiqon, 2012). 
Media mengarah pada sesuatu yang mengantar atau meneruskan informasi (pesan) antara pemberi pesan dan penerima pesan. Media juga merupakan segala bentuk dan saluran yang dapat digunakan dalam suatu proses penyajian informasi. Peran media dalam proses komunikasi adalah sebagai alat pengirim yang mentransfespesan dari pengirim kepada penerima informasi (Latuheru, 1988).

media pembelajaran merupakan sarana/alat pembelajaran yang memiliki dua pengertian pertama, media sebagai sarana/alat yang dapat dijadikan guru untuk mempermudah/memperjelas penyampaian pesan kepada siswa. Kedua, media sebagai alat penyampai pesan kepada siswa, jadi media dalam artian kedua ini media dapat digunakan siswa secara mandiri untuk mendapatkan pesan meskipun tanpa bantuan guru (Faizah, 2019).

Dari beberapa pengertian tersebut, media pembelajaran adalah setiap alat baik perangkat keras maupun perangkat lunak yang digunakan sebagai perantara komunikasi dan interaksi antara guru dan siswa dalam proses pembelajaran untuk menigkatkan efektifitas jenis kegiatan belajar mengajar agar tujuan pembelajaran dapat tercapai.

Sedangkan Kertas Lipat berasal dari Bahasa Jepang yaitu origami yang bermakna 'ori' berarti lipat dan 'gami' berarti kertas. Jadi, origami bermakna melipat kertas. Seni melipat ini pertama kali diperkenalkan di abad pertama zaman Tiongkok kuno tahun 105 Masehi oleh Ts'ai Lun. Kemudian, mulai berkembang dengan pesat di Jepang dan menjadi kebudayaan. Bahkan, setiap aspek kehidupan orang Jepang selalu mengaitkan origami. Kini, seni origami sudah sangat populer di seluruh penjuru dunia.

Di Indonesia, siswa sudah akrab dengan origami sejak usia play group. Bagi mereka, ber-origami adalah bermain dengan kertas. Origami memiliki peran penting sebagai media komunikasi yang menyenangkan antara guru, siswa, juga orangtua. Jika dilatih secara konsisten dan diaplikasikan dengan metode yang tepat, maka bisa meningkatkan daya konsentrasi siswa.

Jenis lipatan origami tradisional biasanya berdasarkan teori matematis, bukan asal lipat. Selain itu, salah satu hal yang menjadi faktor keindahan pada model origami adalah proporsi bentuknya. Setiap lipatan harus proposional. Dengan demikian, aktivitas origami dapat membimbing siswa untuk megenal konsep perbandingan bentuk dan juga berpikir matematis.

Adapun beberapa kelebihan kertas lipat untuk digunakan dalam pembelajaran diantaranya: (1)Kelebihan media kertas lipat; (2) Dapat meningkatkan kreatifitas dalam membuat alat ini; (3) Siswa menjadi lebih aktif dalam memperoleh pembelajaran yang bermakna dari media kertas lipat; (4) Belajar beraktivitas dan meningkatkan kemampuan berfikir; (5) Berfikir matematis; (6) Dapat melatih komunikasi siswa dalam kelompok. (7) Menimbulkan motivasi, dan menimbulkan keceriaan serta menarik perhatian siswa saat mempraktikkan kertas lipat yang berwarna (Yuniarsih, 2006). 


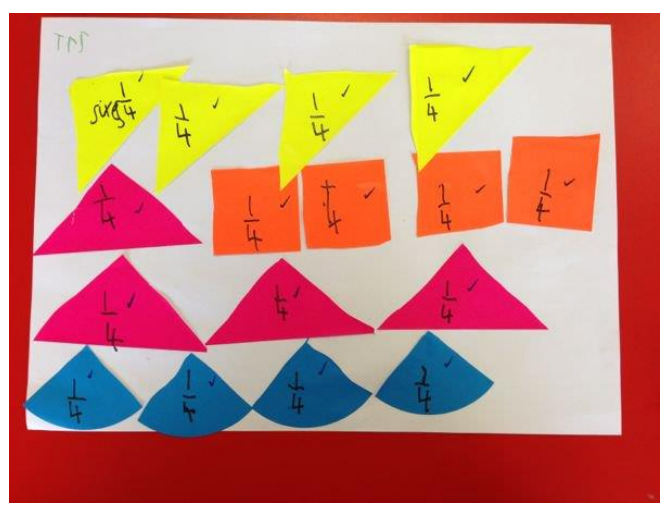

Gambar 1. Media Kertas Lipat Materi Pecahan

\section{Hasil Belajar}

Hasil belajar terdiri dari dua kata, yaitu kata "hasil" dan "belajar". Untuk memahami pengertian kata hasil belajar maka perlu diketahui terlebih dahulu apa yang dimaksud dengan "hasil" dan apa yang dimaksud dengan "belajar". Kata hasil dalam kamus besar bahasa Indonesia mempunyai arti hasil usaha (Arifin, 2016).

Sedangkan belajar dalam kamus besar bahasa Indonesia adalah berusaha untuk memperoleh kepandaian atau ilmu. belajar merupakan suatu proses usaha yang dilakukan seseorang untuk memperoleh suatu perubahan tingkah laku yang baru secara keseluruhan sebagai hasil dari pengalaman sendiri dalam interaksi dengan lingkungannya (Slameto, 2010).

Menurut Dr. Arif S. Sadiman berpendapat bahwa belajar merupakan suatu proses yang kompleks yang terjadi pada semua orang dan berlangsung seumur hidup sejak ia masih bayi hingga ia keliang lahat (meninggal dunia) (Arif S. Sadiman dkk, 2003). Sedangkan menurut Horwart Kingsley dalam bukunya Sudjana membagi tiga macam hasil belajar mengajar : (1). Keterampilan dan kebiasaan, (2). Pengetahuan dan pengarahan, (3). Sikap dan cita-cita (Sudjana, 2019).

Menurut pengertian secara psikologis, belajar merupakan suatu proses perubahan yaitu perubahan tingkah laku sebagai hasil dari interaksi dengan lingkungan dalam memenuhi kebutuhan hidupnya. Perubahan tersebut akan nyata dalam seluruh aspek tingkah laku. Perubahan tingkah laku yang terjadi adalah sebagai berikut: (1) Perubahan terjadi secara sadar, (2) Perubahan dalam belajar bersifat kontinue dan fungsional, (3) Perubahan dalam belajar bersifat positif dan aktif, (4) Perubahan dalam belajar bukan bersifat sementara, (5) Perubahan dalam belajar bertujuan dan terarah, (6) Perubahan dalam belajar mencakup seluruh aspek tingkah laku (Mudjiono, 2013).

Sedangkan hasil belajar adalah sesuatu yang diperoleh berupa kesan-kesan yang mengakibatkan perubahan dalam individu sebagai hasil dari aktivitas belajar (Zain, 
2014). Menurut Jhon A. Van Walle, hasil belajar adalah suatu tindakan penilaian oleh guru terhadap pembelajarannya kepada siswa, serta sebagai tolak ukur berhasil atau tidaknya pengajaran yang telah dilakukannya di kelas (Walle, 2008).

Berdasarkan beberapa pengertian diatas dapat didefinisikan bahwa hasil belajar adalah bentuk perubahan tingkah laku secara menyeluruh yang mencakup tiga aspek yaitu kognitif, afektif dan psikomotor secara terpadu terhadap diri siswa setelah mengalami aktivitas belajar.

\section{Matematika Pecahan}

Secara singkat, bilangan pecahan dapat diartikan sebagai sebuah bilangan yang memiliki pembilang dan juga penyebut. Pada bentuk bilangan ini, pembilang dibaca terlebih dahulu baru disusul dengan penyebut. Ketika menyebutkan suatu bilangan pecahan, diantara pembilang dan penyebut harus disisipkan kata "per". Misalkan untuk bilangan 3/5 maka kita dapat menyebutnya dengan "tiga per lima" begitu juga dengan bilangan 1/4 kalian bisa membacanya "satu per empat" atau "seperempat". Apabila ada bilangan pecahan yang memiliki nilai sama atau nilainya tetap ketika pembilang dan penyebutnya dikalikan/dibagi dengan sebuah bilangan (bukan nol) maka bilangan pecahan tersebut disebut dengan pecahan senilai (Bird, 2004).

Untuk menjelaskan pengertian bilangan pecahan sebagai bagian dari sesuatu yang utuh dapat menggunakan gambar ilustrasi, dimana bagian yang dimaksud adalah bagian yang diperhatikan (ditandai dengan arsiran). Bagian yang diarsir dinamakan pembilang dan yang utuh dianggap sebagai satuan dan dinamakan penyebut.

Pada pecahan terdapat operasi penjumlahan pecahan.Operasi penjumlahan pecahan dibedakan menjadi dua macam, yaitu penjumlahan pecahan yang berpenyebut sama dan penjumlahan pecahan yang berpenyebut beda. Pada dasarnya pengurangan pada pecahan sama saja dengan konsep penjumlahan. Akan tetapi, pengurangan bisa dilakukan langsung apabila penyebutnya sama dan apabila penyebut dari kedua pecahan yang dikurangkan adalah tidak sama (berbeda) maka harus disamakan terlebih dahulu (Retnowati, 2008).

\section{B. Metode}

Penelitian ini merupakan penelitan PTK (penelitian tindakan kelas). Dalam penelitian ini, peneliti menggunakan model atau desain penelitian Kemmis Taggart. Dalam desain penelitian Kemmis merupakan pengembangan dari konsep dasar yang diperkenalkan Kurt Lewin. Desain penelitian Kemmisdikenal dengan model spiral. Dalam perencanaannya Kemmis menggunakan sistem spiral refleksi diri, yang dimulai dengan suatu rencana, tindakan, pengamatan, refleksi dan perencanaan kembali merupakan dasar untuk suatu ancang-ancang pemecahan masalah (Suwandi, 2008). 
Menurut Kemmis, dalam penelitian tindakan kelas dua kegiatan yaitu tindakan dan observasi haruslah dilakukan dalam satu kesatuan waktu, begitu berlangsungnya satu tindakan begitu pula observasi juga dilakukan. Didalam desain penelitian Kemmis dikenal dengan sistem siklus. Artinya dalam satu siklus terdapat suatu putaran kegiatan yang terdiri dari perencanaan, tindakan, pengamatan, dan refleksi. Ketika satu siklus hampir berakhir, namun peneliti masih menemukan kekurangan ketika dilakukan refleksi, maka peneliti bisa melanjutkan pada siklus kedua. Siklus kedua dengan masalah yang sama namun dengan teknik yang berbeda. Sehingga diperoleh perubahan hasil di akhir siklus kedua ini. Adapun tindakan yang diteliti adalah penggunaan media kertas lipat dalam meningkatkan hasil belajar siswa kelas IV pada materi Pecahan Sederhana di MI Ma'arif Nu Sunan Drajat Lamongan.

\section{Hasil dan Pembahasan}

\section{Siklus I}

Penelitian pada siklus I dilaksanakan tanggal 04 Februari 2019, pada tahap perencanaan terdapat beberapa hal yang dilakukan diantaranya menyusun RPP, lembar kerja, dan format penilaian mata pelajaran matematika kelas IV MI Ma'arif NU Sunan Drajat Lamongan. Pada tahap pelaksanaan peneliti melakukan kegiatan pembelajaran sesuai dengan RPP yang telah disusun serta melakukan observasi dan penilaian.

Berdasarkan hasil observasi dan penilaian pada siklus I yang dilakukan selama dua kali pertemuan diperoleh hasil belajar materi pecahan sebagai berikut: 
Tabel 1. Hasil Belajar Siklus I

\begin{tabular}{clc}
\hline NO & \multicolumn{1}{c}{ NAMA } & $\begin{array}{c}\text { Nilai } \\
\text { Siklus 1 }\end{array}$ \\
\hline 1 & Afiqa Abatina Naura & 80 \\
\hline 2 & M. Bagas Nuri S & 80 \\
\hline 3 & Firly Faidatun N.B. & 70 \\
\hline 4 & M. Maulana Kusuma & 70 \\
\hline 5 & Gaf & 70 \\
\hline 6 & Keitara Gamel Firdaus & 80 \\
\hline 7 & M.Husain A.A & 80 \\
\hline 8 & Tarisa Rajwa N & 80 \\
\hline 9 & Akhlis Dinal A & 70 \\
\hline 10 & Genendra Rifqi P. & 70 \\
\hline 11 & Dewi Sinta N. & 70 \\
\hline 12 & Hibriza Dew A & 80 \\
\hline 13 & M. Alfa Rizqy & 90 \\
\hline 14 & Aqila Qaisara F & 100 \\
\hline 15 & Nabila Cherryl & 80 \\
\hline 16 & M. Al aliyu budu A & 80 \\
\hline 17 & Barrozatur Robiah & 80 \\
\hline 18 & Gading Rahmadina & 80 \\
\hline & & \\
\hline
\end{tabular}

\begin{tabular}{clc}
\hline NO & \multicolumn{1}{c}{ NAMA } & $\begin{array}{c}\text { Nilai } \\
\text { Siklus 1 }\end{array}$ \\
\hline 19 & Girindra Hafidhatur R & 70 \\
\hline 20 & Luthfiah Salsa C & 40 \\
\hline 21 & Inas Insiyah & 0 \\
\hline 22 & Ach. Kemal Reza & 50 \\
\hline 23 & Farial Zaharis & 60 \\
\hline 24 & Rizki Akbar Nugraha & 50 \\
\hline 25 & Nathania Amorita A & 40 \\
\hline 26 & Ananda Tyas & 40 \\
\hline 27 & M. Ghayaka Enzo & 60 \\
\hline 28 & Maulida Faizatin t & 20 \\
\hline 29 & Afifah Anggraeny & 40 \\
\hline 30 & Alno Nainus Rhama P & 70 \\
\hline 31 & Nadia Zahra A & 60 \\
\hline 32 & Shella Milda F & 30 \\
\hline 33 & Ach. Sulthon Fanani & 60 \\
\hline 34 & Alisha Fatimah Azzahra & 70 \\
\hline & & 64 \\
& & \\
\hline & &
\end{tabular}

Berdasarkan tabel hasil observasi terhadap keaktifan siswa dalam melaksanakan kegiatan pembelajaran Matematika siklus I menunjukkan adanya peningkatan hasil belajar sebelum dilakukan tindakan (Pra Siklus/Pre test) rata-rata hasil belajar pada kategori "rendah" yaitu 57, kemudian setelah dilakukan perlakuan menggunakan media kertas lipat rata-rata hasil belajar rata-ratanya meningkat menjadi 65 dengan kategori "Sedang". Pada siklus I terdapat 21 siswa tuntas KKM dengan persentase $62 \%$ dan siswa yang tidak tuntas KKM 13 siswa dengan persentase $38 \%$.

Belum maksimalnya ketuntasan siswa mencapai $75 \%$ dipengaruhi oleh beberapa factor: (1) pelaksanaan pembelajaran dengan media kertas lipat masih dilakukan secara klasikal per individu, (2) guru belum mampu mengkondisikan seluruh siswa untuk menggunakan kertas lipat dengan benar dalam menghitung pecahan.

Siklus II 
Berdasarkan hasil refleksi pada siklus I, dilakukan perbaikan perencanaan pada siklus II berupa perbaikan kegiatan pembelajaran berbasis kelompok pada RPP. Dan mempersiapkan soal formatif II. Siklus II dilaksanakan pada 08 Februari dengan proses pembelajaran berdasarkan RPP yang direvisi dari siklus I, yaitu melaksanakan pembelajaran secara berkelompok yang memungkinkan antar anggota kelompok dapat saling membantu cara penggunaan kertas lipat dalam menghitung materi pecahan, sehingga guru dapat mengkondisikan siswa pada setiap kelompok dengan baik.

Setelah dilakukan perencanaan sesuai dengan hasil refleksi pada siklus I, hasil belajar siswa kelas IV MI Ma'arif NU Sunan Drajat pada siklus II adalah sebagai berikut:

Tabel 2. Hasil Belajar Siklus II

\begin{tabular}{|c|c|c|c|c|c|}
\hline NO & NAMA & $\begin{array}{c}\text { Nilai } \\
\text { Siklus II }\end{array}$ & NO & NAMA & $\begin{array}{c}\text { Nilai } \\
\text { Siklus II }\end{array}$ \\
\hline 1 & Afiqa Abatina Naura & 100 & 19 & Girindra Hafidhatur R & 70 \\
\hline 2 & M. Bagas Nuri S & 80 & 20 & Luthfiah Salsa C & 100 \\
\hline 3 & Firly Faidatun N.B. & 100 & 21 & Inas Insiyah & 100 \\
\hline \multirow{2}{*}{4} & \multirow{2}{*}{$\begin{array}{l}\text { M. Maulana Kusuma } \\
\text { Gaf }\end{array}$} & \multirow{2}{*}{80} & 22 & Ach. Kemal Reza & 70 \\
\hline & & & 23 & Farial Zaharis & 70 \\
\hline 5 & $\begin{array}{l}\text { Sayyida Ufaira } \\
\text { Chafsoh }\end{array}$ & 60 & 24 & Rizki Akbar Nugraha & 60 \\
\hline 6 & Keitara Gamel Firdaus & 80 & 25 & Nathania Amorita A & 100 \\
\hline 7 & M.Husain A.A & 80 & 26 & Ananda Tyas & 100 \\
\hline 8 & Tarisa Rajwa N & 100 & 27 & M. Ghayaka Enzo & 70 \\
\hline 9 & Akhlis Dinal A & 90 & 28 & Maulida Faizatin $t$ & 50 \\
\hline 10 & Genendra Rifqi P. & 80 & 29 & Afifah Anggraeny & 100 \\
\hline 11 & Dewi Sinta N. & 100 & 30 & Alno Nainus Rhama P & 90 \\
\hline 12 & Hibriza Dew A & 80 & 31 & Nadia Zahra A & 80 \\
\hline 13 & M. Alfa Rizqy & 100 & 32 & Shella Milda F & 70 \\
\hline 14 & Aqila Qaisara F & 100 & 33 & Ach. Sulthon Fanani & 70 \\
\hline 15 & Nabila Cherryl & 80 & 34 & $\begin{array}{l}\text { Alisha Fatimah } \\
\text { Azzahra }\end{array}$ & 80 \\
\hline 16 & M. Al aliyu budu A & 100 & & Rata-rata & 84 \\
\hline 17 & Barrozatur Robiah & 80 & & Kata-rata & 04 \\
\hline 18 & Gading Rahmadina & 90 & & & \\
\hline
\end{tabular}

Berdasarkan tabel 2. Dapat disimpulkan adanya peningkatan rata-rata hasil belajar pada siklus I yaitu 64 dan setelah dilakukan pembelajaran dengan siklus II menunjukkan 
rata-rata hasil belajar siswa meningkat menjadi 84. Peningkatan hasil belajar tersebut dapat dilihat dengan tabel berikut.

Tabel 3. Hasil Belajar Matematika Siklus I dan II

\begin{tabular}{|l|c|c|}
\hline \multicolumn{1}{|c|}{ Statistik } & Siklus I & Siklus II \\
\hline Nilai Tertinggi & 100 & 100 \\
\hline Nilai Terendah & 20 & 50 \\
\hline KKM & 70 & 70 \\
\hline Rata-rata & 65 & 84 \\
\hline Tuntas & $62 \%$ & $91 \%$ \\
\hline Belum Tuntas & $38 \%$ & $9 \%$ \\
\hline
\end{tabular}

Pada tabel 3 rata-rata hasil belajar siswa mengalami peningkatan dari siklus I dan siklus II yaitu 65 pada siklus I meningkat menjadi 84 pada siklus II. Pada tingkat ketuntasan belajar pada siklus II mencapai 91\% telah mencapai KKM yaitu 70. Dengan demikian pembelajaran matematika materi pecahan di kelas IV dikatakan telah mencapai pembelajaran tuntas yaitu $\geq 85 \%$ siswa telah mencapai KKM (Zulistiyanto, 2018).

\section{Simpulan}

Berdasarkan analisis data penelitian tindakan kelas terhadap peningkatan hasil belajar matematika materi pokok bahasan operasi hitung penjumlahan pecahan berpenyebut tidak sama melalui media kertas lipat bagi siswa kelas IV E MI Ma'arif NU Sunan Drajat Lamongan yang berjumlah 34 siswa dengan 14 siswa laki-laki dan 20 siswa perempuan. Disimpulkan bahwa pembelajaran matematika dengan kompetensi dasar "Membandingkan Pecahan" dengan menggunakan media kertas lipat dapat meningkatkan hasil belajar. Sehingga siswa dapat dibelajarkan lebih memahami konsep membandingkan pecahan berpenyebut tidak sama. Hal ini terbukti dengan adanya peningkatan hasil belajar siswa yang dicapai setelah dilaksanakan tindakan perbaikan.

Dari hasil pre test pembelajaran belum menggunakan media pembelajaran nilai rata-rata 57,34, pada siklus I dan siklus II setelah menggunakan media pembelajaran terjadi peningkatan, yaitu pada siklus I nilai rata-rata mencapai 65 dan pada siklus II niai rata-rata mencapai 84 . Berdasarkan perhitungan pada pre tes, siklus I dan siklus II terjadi peningkatan hasil belajar siswa. Oleh karena itu, terbukti bahwa penggunaan media kertas lipat berpengaruh terhadap kemampuan dan pemahaman siswa dalam menerima pelajaran matematika khususnya pada pokok bahasan membandingkan bilangan pecahan berpenyebut tidak sama. 


\section{Daftar Rujukan}

Admin. (2011). Pembelajaran Matematika di Sekolah Dasar. Retrieved from https://www.sekolahdasar.net/2011/07/pembelajaran-matematika-di-sekolah.html

Arif S. Sadiman dkk. (2003). Media Pendidikan Pengertian Pengembangan dan Manfaatnya. Jakarta: Raja Grafindo Persada.

Arifin, Z. (2016). Evaluasi Pembelajaran. Jakarta: PT. Remaja Rosda Karya.

Bird, J. (2004). Pembelajaran Matematika. Jakarta: Bumi aksara.

Faizah, U. K. dan S. N. (2019). Media Pembelajaran tematik. Malang: Inteligensia Media.

Latuheru, J. (1988). Media Pembelajaran. Jakarta: Raja Grafindo.

Mudjiono, D. dan. (2013). Belajar dan Pembelajaran. Jakarta: Rineka Cipta.

Musfiqon. (2012). Pengembangan Media \& Sumber Pembelajaran. Jakarta: Prestasi Pustakarya.

Nasution, A. H. (1992). Kalkulus dan Geometri. Jakarta: Erlangga.

Retnowati, H. (2008). Matematika Untuk SD Kelas IV. Jakarta: Arya Duta.

Slameto. (2010). Belajar dan Faktor-faktor yang Mempengaruhinya. Jakarta: Rineka Cipta.

Sudjana, N. (2019). Dasar-dasar Proses Belajar Mengajar. Bandung: Sinar Baru Algensido Offset.

Suwandi, B. dan. (2008). Prosedur Penelitian Tindakan Kelas. Bogor: Ghalia Indonesia.

Syaodih, M. S. dan N. (2006). Perkembangan Peserta Didik. Jakarta: Universitas Terbuka.

Titikusumawati, E. (2014). Modul Pembelajaran Matematika. Jakarta: Kementrian Agama Republik Indonesia.

Walle, J. A. Van. (2008). Matematika Sekolah Dasar dan Menengah. Bandung: Erlangga.

Yuniarsih. (2006). Meningkatkan Hasil Belajar Siswa Pada Pokok Bahasan Pecahan Dengan Alat Peraga Kertas Lipat. Jakarta: Rineka Cipta.

Zain, S. B. D. dan A. (2014). Strategi Belajar Mengajar. Jakarta: Rineka Cipta.

Zulistiyanto, D. (2018). Penerapan Model Belajar Tuntas (Mastery Learning) dalam Meningkatkan Prestasi Belajar Siswa MI Roudlotul Huda. Jurnal Profesi Keguruan, 4(1). Retrieved from https://journal.unnes.ac.id/nju/index.php/jpk 